International Journal on Applied Bioengineering, Vol. 5 No. 2 July 2011

\title{
BIOTRANSFORMATION OF HEXAVALENT TO TRIVALENT CHROMIUM IN INDUSTRIAL EFFLUENTS
}

\author{
Rangasamy Parthiban ${ }^{1}$, Meenatchisundaram Sivarajan ${ }^{2}$ \\ 1,Professor and Head, Department of Chemical Engineering \\ Sri Venkateswara College of Engineering, Sriperumbudur, India \\ ${ }^{2}$ Scientist, Central Leather Research Institute, Chennai, India \\ Email: ${ }^{1}$ rparthi@yahoo.com, ${ }^{2}$ sivarajan_s@ hotmail.com
}

\section{ABSTRACT}

In this research work, a locally isolated strains of Pseudomonas $s p$., and consortium of bacteria is used to reduce toxic hexavalent chromium to less toxic trivalent chromium at concentrations of $100,200,300$ and $400 \mathrm{mg} / \mathrm{L}$, respectively at $\mathrm{pH} 7$ and temperature $30^{\circ} \mathrm{C}$. Even though increasing the concentration of $\mathrm{Cr}(\mathrm{VI})$ in the medium decreased the growth rate showing the detrimental effect of this heavy metal, it could not be directly correlated with the amount of $\mathrm{Cr}(\mathrm{VI})$ reduced. The consortium of bacteria showed higher rate of reduction in $300 \mathrm{mg} / \mathrm{L}$ with overall reduction of $90.41 \%$ but the Pseudomonas sp., could show reduction up to $90 \%$ in the $100 \mathrm{mg} \mathrm{I}^{-1}$ initial concentration of hexavalent chromium only. High $\mathrm{Cr}(\mathrm{VI})$ concentration resistance and high $\mathrm{Cr}(\mathrm{VI})$ reducing ability of the analyzed strains make them suitable for additional studies related to bioremediation of hexavalent chromium.

Key words: Bioremediation, Pseudomonas, Chromium removal, Consortium of microbes

\section{INTRODUCTION}

Novel biotechnological approaches to the abatement of metal pollution consist of selectively using and enhancing the natural processes to treat particular wastes. Hexavalent chromium compounds are being used in a wide variety of commercial processes and National Institute for Occupational Safety and Health (NIOSH) has classified it as a potential occupational carcinogen. The unregulated disposal of the chromium containing effluent has led to the contamination of soil, sediment, surface and ground waters (Srinath $\mathrm{T}$ et al 2002).

Reduction of hexavalent chromium to non toxic trivalent form by chromium resistant bacteria (CRB) is found to have both economical and eco-friendly option for chromate detoxification and bioremediation ( $\mathrm{Pal}$ et al., 2005). The set of processes by which microorganisms react with toxic metals enabling their removal, reduction and recovery are biosorption, bioaccumulation and enzymatic reduction (Srinath et al., (2002))

It is interesting to note, however, that chromium, especially under its reduced form, is a useful trace element in living organisms, including higher animals and, since it increases cells sensitivity to insulin, chromium was proposed as dietary additive to prevent diabetes (Miranda and Dey, 2004).It is widely believed that reduction to trivalent chromium is the final pathway step in the microbial hexavalent chromium reduction chain because bacterial cells become encrusted with chromium-rich precipitates (Wang et al., 1990) and $\mathrm{Cr}(\mathrm{III})$ is the only stable, insoluble form. Even though many microorganisms are able to reduce hexavalent to trivalent chromium, the potential for biological treatment of hexavalent $\mathrm{Cr}$ contaminated waste is limited because majority of these bacteria cannot tolerate high concentrations of chromate (Zhu et al., 2008).

The objective of the present study is to see the ability of bacteria which can grow in chromium polluted environment and at the same time having the ability to reduce toxic hexavalent chromium is exploited in our studies for reducing the artificially amended hexavalent source of chromium $\left(\mathrm{K}_{2} \mathrm{Cr}_{2} \mathrm{O}_{7}\right)$ and also a consortium of bacteria which is being isolated and sub-cultured from the effluent sample collected from common effluent treatment plant, Pallavaram, Chennai, Tamilnadu, India, where the rest of the microorganisms were also isolated their ability of chromium reducing was monitored with optimizing other essential parameters of bacteria isolated from the effluent sample isolated from the tannery effluent site. The paper is organized as follows: section 2 deals with literature survey, section 3 with materials and methods, section 4 with experimental results and section.5 with conclusions. 


\section{REVIEW OF LITERATURE}

Certain Pseudomonas strain was first separated from chromate containing sewage sludge and used to reduce $\mathrm{Cr}(\mathrm{VI})$ to $\mathrm{Cr}(\mathrm{III})$ under anaerobic condition in the 1970's (Romanenko and Korenkov, 1977). From then onwards a variety of genera bacteria, such as Arthrobacter (Nino et al., 2004), Enterobacter (Wang et al., 1989), Escherichia (Wang and Shen, 1995), Pseudomonas (Mclean and Beveridge, 2001), Shewanella (Guha et al., 2001) were found to have chromate-reducing ability as discussed by W. Zhu et al., 2006. Enzymatic reduction of chromate is reported in many bacteria (Ohtake and Silver, 1994)

Some micro-organisms have the unique ability to adapt to environments with elevated metal concentrations, and different strains have been evaluated for reducing $\mathrm{Cr}(\mathrm{VI})$ to $\mathrm{Cr}(\mathrm{III})$ (Fude et al., 1994; Lovely and Phillips,1994; Cher and Hao 1996) To date, most of the heavy metal bioremediation research has been focused on aqueous-based contaminants using pure cultures such as Pseudomonas putida (Ishibashi et al., 1990), desulfovibrio vulgaris (Lovely and Phillips, 1994), and Escherichia coli (Shen and Wang, 1993).

It has been reported that hexavalent chromium is reduced to trivalent chromium by a number of bacterial species like Pseudomonas fluorescens LB300, Bacillus $s p$., Enterobacter cloacae $\mathrm{HO} 1$ and Enterobacter aerogenes (Bopp LH at al., 1983). Hexavalent chromium has been shown to serve as the final electron acceptor in respiratory chains of $B$. subtilis (Gvozdyak et al., 1986), P.aeruginosa (Gvozdyak et al., 1986), P. fluorescens (Bopp and Ehrlich, 1988), and Enterobacter cloacae (Wang et al., 1990). In the absence of oxygen and nitrate, $\mathrm{Cr}(\mathrm{VI})$ was shown to be quantitatively transformed to $\mathrm{Cr}$ (III) largely by soluble reductase activity in E. coli (Shen and Wang, 1993).

A slight elevation in the level of $\mathrm{Cr}^{6+}$ elicits environmental and health problems because of its mutagenicity (Nishioka, 1975), high toxicity (Petrilli and Flora, 1977; Sharma et al., 1995), and carcinogenicity (Venitt and Levy, 1974). Under normal physiological conditions, $\mathrm{Cr}^{6+}$ reacts spontaneously with the intracellular reductants (e.g. ascorbate and glutathione) to generate the short-lived intermediates $\mathrm{Cr}^{5+}$ and/or
$\mathrm{Cr}^{4+}$, free radicals and the end-product $\mathrm{Cr}^{3+}$ (Costa, 2003; Xu et al., 2005). $\mathrm{Cr}^{5+}$ undergoes a one-electron redox cycle to regenerate $\mathrm{Cr}^{6+}$ and transferring the electron oxygen. The process produces a reactive oxygen species (ROS) that easily combines with DNA-protein complexes.

$\mathrm{Cr}^{4+}$ would bind to cellular materials and deter their normal physiological functions (Pesti et al., 2000; Cervantes et al., 2001). In humans, several traumata are associated with $\mathrm{Cr}^{6+}$ exposure, including nasal irritation and ulceration, skin irritation, eardrum perforation and lung carcinoma (Gibb, et al., 2006). Furthermore, $\mathrm{Cr}^{6+}$ can accumulate in the placenta, impairing fetal development in mammals (Saxena et al., 1990). In the environment, $\mathrm{Cr}^{6+}$ contamination alters the structure of soil microbial communities (Zhou et al., 2002; Turpeinen et al., 2004). As a result of reduced microbial growth and activities, organic matter accumulates $\mathrm{Cr}^{6+}$ in soils (Mazierski, 1995; Shi et al., 2002).

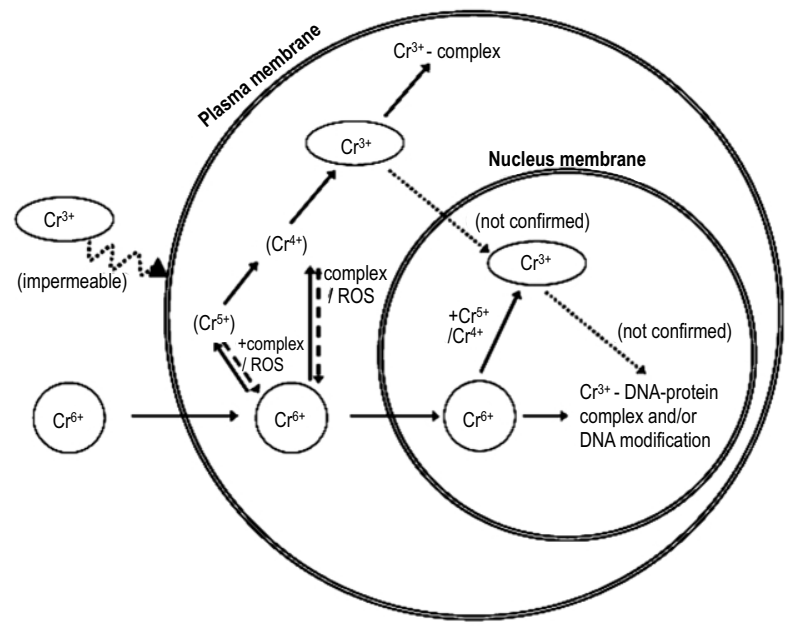

Fig. 1. Schematic diagram of toxicity and mutagenicity of $\mathrm{Cr}^{6+}$.

The intracellular $\mathrm{Cr}^{6+}$ reductants naturally available are frequently obligatory one electron reducers, which generate $\mathrm{Cr}^{5+}$ and a large amount of ROS that causes the deleterious effects of $\mathrm{Cr}^{6+}$ (Cheung and Gu 2007)

In a study conducted by Srinath et al, (2002) strains that are capable of bioaccumulating $\mathrm{Cr}(\mathrm{VI})$ were 
isolated from treated tannery effluent of a common effluent treatment plant. Biosorption of $\mathrm{Cr}(\mathrm{VI})$ was shown by $B$. megaterium and an another strain, $B$. coagulans. Living and dead cells of $B$. coagulans biosorbed 23.8 and $39.9 \mathrm{mg} \mathrm{Cr} / \mathrm{g}$ dry weight, respectively, whereas, 15.7 and $30.7 \mathrm{mg} \mathrm{Cr} / \mathrm{g}$ dry weight was biosorbed by living and dead cells of $B$. megaterium, respectively. Biosorption by the dead cells was higher than the living cells.

During the studies conducted on chromium toxicity in actinomycetes, a strain of Streptomyces griseus was found to grow and reduce highly toxic $\mathrm{Cr}(\mathrm{VI})$ to less toxic $\mathrm{Cr}(\mathrm{III})$ from media containing 5-60 ppm of $\mathrm{Cr}(\mathrm{VI})$. Conversion of $\mathrm{Cr}(\mathrm{VI})$ to $\mathrm{Cr}(\mathrm{III})$ was complete within 24-48 hr of chromium addition with significant uptake in the biomass. Reduction of chromium by resting cells and effect of various factors on chromium reduction was observed by Laxman and More (2002).

\section{MATERIALS AND METHODS}

The glasswares were sterilized in a hot air oven at $180^{\circ} \mathrm{C}$ for three hours or autoclaved at $121^{\circ} \mathrm{C}$ for $15 \mathrm{~min}$ at $15 \mathrm{lb}$ according to the requirement.

\section{A. Analysis of the growth of micro organism}

Nutrient broth amended with various initial concentration of chromium ranging from 100 to 400 $\mathrm{mg} / \mathrm{L}$ was inoculated with bacterial culture so as to get an absorbance of 0.05 , from overnight grown cultures it was incubated at $37^{\circ} \mathrm{C}$ under shaking condition (100 $\mathrm{rev} / \mathrm{min})$. Aliquots $(10 \mathrm{~mL})$ were withdrawn at regular time interval and analyzed for growth at $600 \mathrm{~nm}$ UV-Visible Scanning Spectrophotometer (Shimadzu UV-2101 PC) and theexperiments were done in triplicates.

\section{B. Analysis of the sample in Chromium reduction}

Chromium reduction was monitored by means of color at varying predetermined time intervals from

1 to $72 \mathrm{hr}$. The reaction mixture was separated from biomass by centrifuging the sample at $12000 \mathrm{rpm}$ for 15 minutes and the residual Chromium concentration was determined using the standard DPC method (Thacker et al., 2006) and a calibration curve prepared at the corresponding optimum wavelength in UV-Visible Scanning Spectrophotometer (Shimadzu UV-2101 PC). Effect of $\mathrm{pH}$, quantity of biomass, concentration, agitation and temperature was monitored. The $\mathrm{pH}$ of initial aqueous solution was adjusted using $0.1 \mathrm{~N} \mathrm{HCl}$ solutions and $1 \mathrm{~N} \mathrm{NaOH}$ solution.

C. Isolation and identification of potential bacteria from chromium contaminated sites both from soil and effluent for reduction of chromium.

\section{Collection of soil samples}

The effluent samples for the isolation of elite microorganisms were collected from effluent collection site at Common Effluent Treatment Plant, Pallavaram, Chennai, Tamilnadu. Soil and effluent samples were collected in polyethylene bags and sterilized containers, and stored at $4^{\circ} \mathrm{C}$ in a refrigerator for further analysis.

\section{Biological properties}

The population of different groups of microorganisms was enumerated in the effluent samples using the standard serial dilution plating technique (Jenson, 1968). (Table 1)

Table 1. Biological properties

\begin{tabular}{|c|l|c|l|}
\hline S.No & Organism & $\begin{array}{c}\text { Dilution } \\
\text { factor }\end{array}$ & Media Used \\
\hline 1. & Bacteria & $10-6$ & Nutrient agar \\
\hline 2. & Fungi & $10-4$ & $\begin{array}{l}\text { Martin rose } \\
\text { bengal agar }\end{array}$ \\
\hline 3. & Actinomycetes & $10-3$ & Kenknight's agar \\
\hline
\end{tabular}

D. Isolation of consortium of Bacteria

In order to get the maximum efficacy in Chromium reduction, a consortium bacterium was isolated from contaminated effluent samples the same were collected from CETP, Pallavaram. $1 \mathrm{~mL}$ of effluent sample with $9 \mathrm{~mL}$ of double distilled water were taken in $90 \mathrm{~mL}$ sterile water blanks and serially diluted to using sterile water blank. After thorough shaking, $1 \mathrm{~mL}$ of aliquot from $10^{6}$ dilutions was drawn and poured in nutrient broth (Riker and Riker, 1936). and the broth was incubated at $30^{\circ} \mathrm{C}$ for 4 days

\section{E. Typical medium composition used in the experiment}

The medium composition, Nutrient Agar Medium and Nutrient broth used in the experiment are presented in Table 2 and Table 3 respectively. 
Table 2. Nutrient Agar Medium

\begin{tabular}{|l|c|}
\hline Typical Composition & g/litre \\
\hline Peptones & 15.0 \\
\hline Yeast extract & 3.0 \\
\hline Sodium chloride & 6.0 \\
\hline D (+) glucose & 1.0 \\
\hline Agar-agar & 12.0 \\
\hline
\end{tabular}

Table 3. Nutrient Broth

\begin{tabular}{|l|c|}
\hline Typical Composition & g/litre \\
\hline Peptones & 15.0 \\
\hline Yeast extract & 3.0 \\
\hline Sodium chloride & 6.0 \\
\hline D (+) glucose & 1.0 \\
\hline
\end{tabular}

\section{F. Screening of potential bacterial cultures}

The identified Bacteria were screened based on the growth on media containing Chromium for its resistance activity. Nutrient broth was amended with $100 \mathrm{mg} / \mathrm{L}$ of $\mathrm{K}_{2} \mathrm{Cr}_{2} \mathrm{O}_{7}$ which was incubated at $30^{\circ} \mathrm{C}$ for $24 \mathrm{hr}$ on orbital shaker. After $24 \mathrm{hr}$ enriched bacterial strains were isolated by plating on Luria agar plate amended with 100,150 and $200 \mathrm{mg} / \mathrm{L}$ of $\mathrm{K}_{2} \mathrm{Cr}_{2} \mathrm{O}_{7}$. plates were observed for growth tolerance of the cultures. The same was done for the consortium of bacteria which was obtained.

\section{G. Finding the microbial reduction of chromium}

The chromium solutions were scanned in UV spectrophotometer to ascertain the wavelength and the maximum absorbance was observed at $540 \mathrm{~nm}$ for Chromium estimation mainly of Chromium reduced content was estimated as the decrease in chromium concentration in supernatant with time using hexavalent chromium specific colorimetric reagent S-diphenyl carbazide (DPC) by Spectrophotometric measurements (Table 4) which were made immediately at $540 \mathrm{~nm}$ in (Shimadzu UV-2101 PC).The rate of reduction was monitored at this respective wavelength.
Table 4. Sample preparation for Chromium reduction and estimation at $540 \mathrm{~nm}$

\begin{tabular}{|c|c|c|c|}
\hline $\begin{array}{c}\text { Amount } \\
\text { of Sample } \\
(\mathrm{mL})\end{array}$ & $\begin{array}{c}\text { Amount } \\
\text { of DPC } \\
(\mathrm{mL})\end{array}$ & $\begin{array}{c}\text { Amount } \\
\text { of } \mathrm{H}_{2} \mathrm{SO}_{4} \\
(\mathrm{~mL})\end{array}$ & $\begin{array}{c}\text { Amount } \\
\text { of } \\
\text { distilled } \\
\text { water }(\mathrm{mL})\end{array}$ \\
\hline 0.4 & 0.4 & 0.4 & 8.8 \\
\hline
\end{tabular}

H. Identification of isolated bacteria

The isolated bacterial cultures were grown on the Nutrient agar medium for 5-7 days and characterized in the laboratory.

Table 5. Taxonomical classification of the organisms for the isolated strain Pseudomonas alcaligenes

\begin{tabular}{|l|l|}
\hline Classification & \multicolumn{1}{|c|}{ Organism } \\
\hline Kingdom & Bacteria \\
\hline Phylum & Proteobacteria \\
\hline Class & GammaProteobacteria \\
\hline Order & Pseudomonadales \\
\hline Family & Pseudomonadaceae \\
\hline Genus & Pseudomonas \\
\hline Species & P. alcaligenes \\
\hline
\end{tabular}

Table 6. Taxonomical classification of the organisms for the isolated strain Pseudomonas putida

\begin{tabular}{|l|l|}
\hline Classification & \multicolumn{1}{|c|}{ Organism } \\
\hline Kingdom & Bacteria \\
\hline Phylum & Proteobacteria \\
\hline Class & GammaProteobacteria \\
\hline Order & Pseudomonadales \\
\hline Family & Pseudomonadaceae \\
\hline Genus & Pseudomonas \\
\hline Species & P. putida \\
\hline
\end{tabular}


The results confirmed that the isolated strains were found to be Pseudomonas alcaligenes (Table 5) and Pseudomonas putida (Table 6) and at the same time the consortium of bacteria was also maintained.

\section{RESULTS AND DISCUSSION}

\section{A. Effect of initial inoculum concentration in reduction of Chromium}

The influence of various inoculum concentrations on reduction of Chromium was found to be almost same in all the case in bioremediation as $2 \%$ of the solution and hence the same was used in this study also

\section{B. Effect of $\mathrm{pH}$ in reduction of Chromium}

In general, the reduction of Chromium set at $\mathrm{pH}$ 7.0 supported higher Chromium reduction. At $\mathrm{pH}$ value greater than 8.0 the reduction of Chromium recorded the lowest value. The reason why reduction activity could be affected by initial $\mathrm{pH}$ of solution is not that bacterial growth had been influenced by $\mathrm{pH}$ value. Maximum conversion of hexavalent to trivalent form was observed in the $\mathrm{pH}$ range of 6-7. (Laxman, and More, 2002).

\section{Effect of temperature in reduction of Chromium}

In general, $30^{\circ} \mathrm{C}$ appeared optimum for the Chromium reduction by the reported that $\mathrm{pH} 6.5$ and a temperature of $30^{\circ} \mathrm{C}$ are favorable for good growth and reductase activity of Pseudomonas alcaligenes, Pseudomonas putida and consortium of bacterial isolates. The highest of reduction was found at $30^{\circ} \mathrm{C}$.
D. Effects of agitation in the reduction of Chromium

The reduction was higher at dynamic condition of at $100 \mathrm{rpm}$ for the Pseudomonas $\mathrm{Sp}$. and this is taken as standard from the earlier works done in this field. (Figure 2)

\section{E. Growth of microbes in chromium amended medium}

The Cr-resistant isolates that were obtained during the study were grown in pure culture and attempts were made to study the chromium reduction by the Pseudomonas Putida, Pseudomonas alcaligenes and the consortium of bacteria. These were grown in varying concentration of chromium amended medium. The growth of bacteria was measured at optical density at $600 \mathrm{~nm}$ (OD600). (Mujeeb ur Rahman et., al, 2007). As expected, very good growth and reduction was achieved in the mixed cultures which were obtained from the tannery effluent site which is usually site of chromium contamination.

It is clearly inferred from the graphs plotted with respect to time and optical density at $600 \mathrm{~nm}$ (figure 3) that the growth of consortium of microbes showed higher growth rate when compared to the Pseudomonas Putida (figure 4) and Pseudomonas Alcaligenes, (figure 5) which also showed considerable growth. This inferred clearly that the organisms with more exposure to chromium environment can readily withstand to the chromium level and they tend to adapt themselves much easier than the other isolates and the consortium has synergic effect over the other isolated

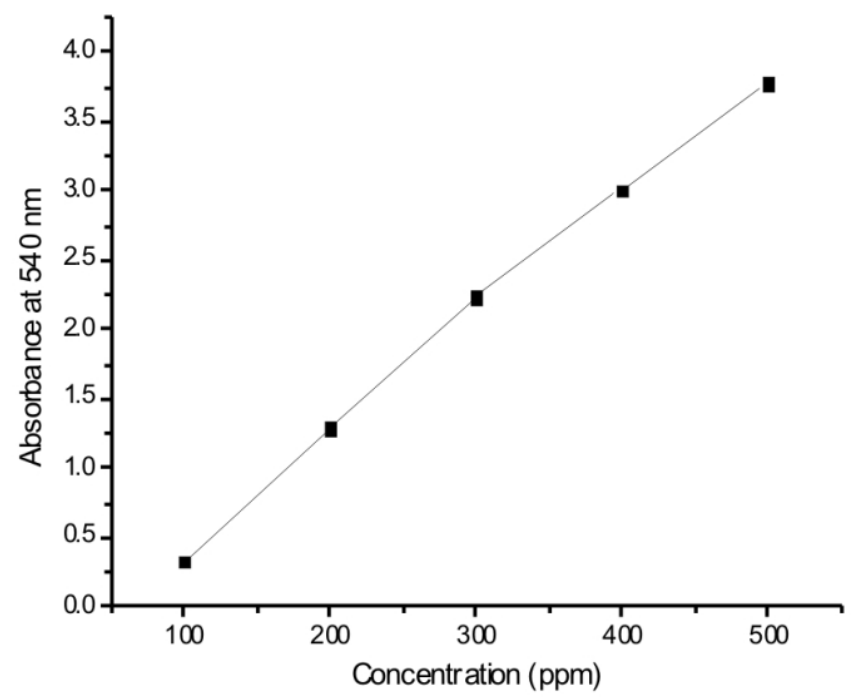

Fig. 2. Standard curve for chromium 


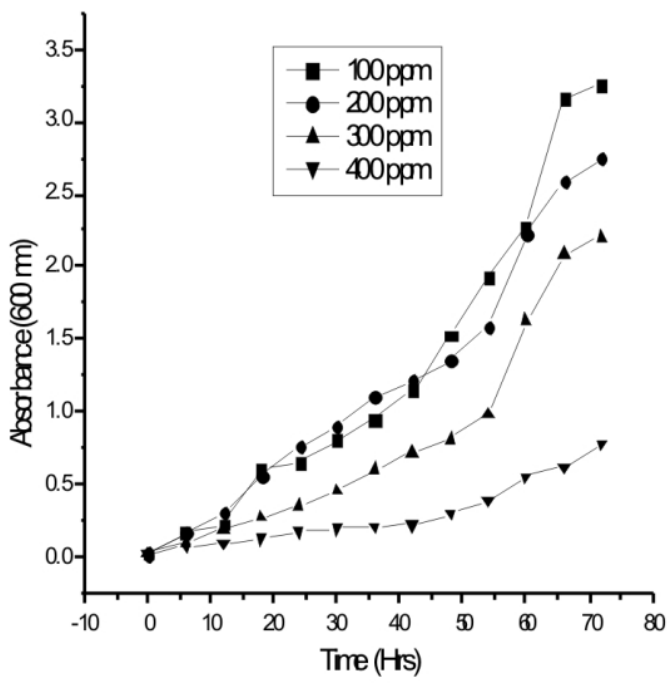

Fig. 3. Growth of Consortium of microbes in various concentration of Chromium amended medium

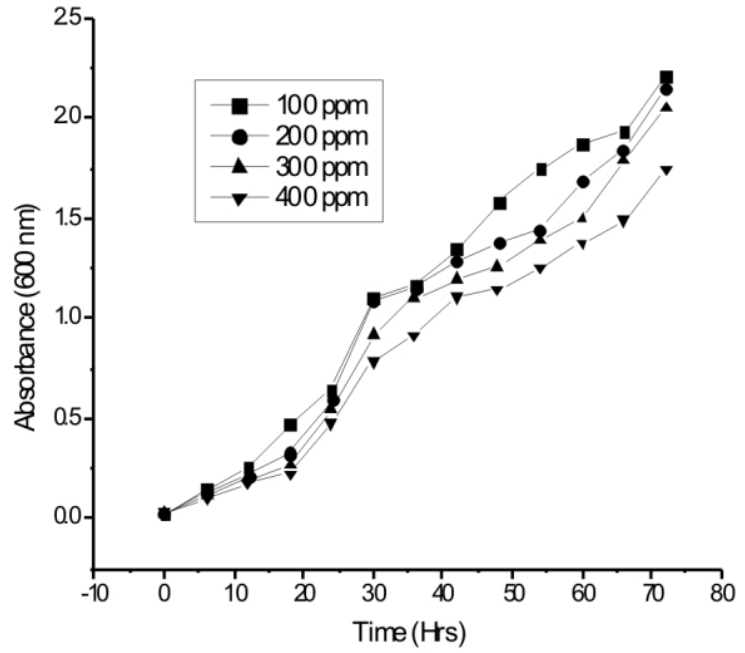

Fig. 4. Growth of Pseudomonas putida in various concentration of Chromium amended medium

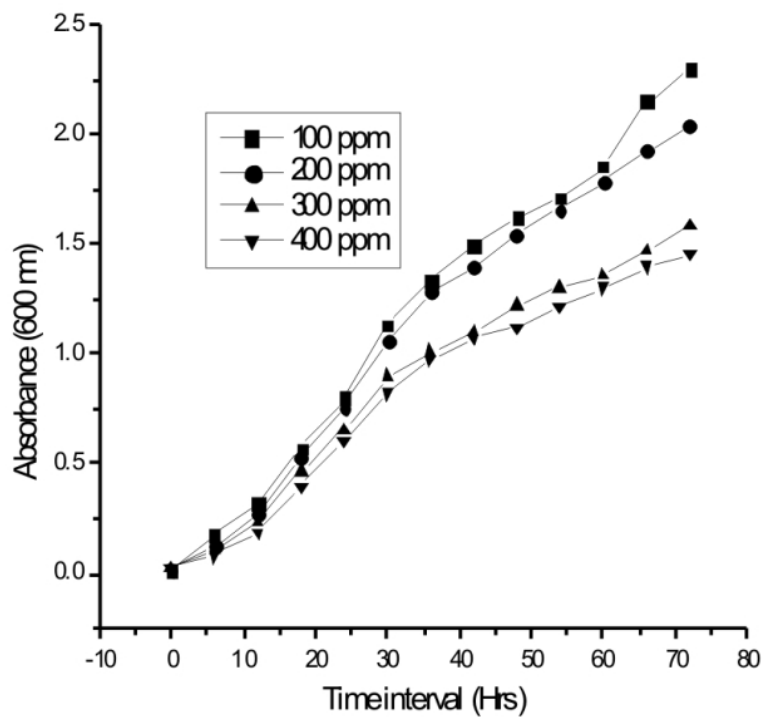

Fig. 5. Growth of Pseudomonas alcaligenes in various concentration of Chromium amended medium 
organisms in the reduction of the chromium. It is inferred that there can be considerable reduction chromium level as there is growth of microorganism in chromium amended medium.

\section{F. Effect of initial concentration of Chromium}

The chromium concentration was varied by the stock solution prepared using $\mathrm{K}_{2} \mathrm{Cr}_{2} \mathrm{O}_{7}(2.38 \mathrm{gm} / \mathrm{L})$ which gives chromium concentration of $1000 \mathrm{ppm}$ from which the required quantity of chromium concentrations necessary was prepared and made to $50 \mathrm{~mL}$ of working solution. The $\mathrm{pH}$ was varied using the phosphate buffer solutions prepared using the mixture of mono potassium hydrogen phosphate and dihydrogen phosphate required to the desired $\mathrm{pH}$ which is 7 and the temperature was set to be a constant as $30^{\circ} \mathrm{C}$ in the orbital shaker at $100 \mathrm{rpm}$. The entire process is done aseptically.

Once the medium amended with varying chromium concentration was prepared then carefully the isolates were transferred into each of the chromium amended medium. The isolates were inoculated on the basis of $2 \%$ of the solution used for the experimental

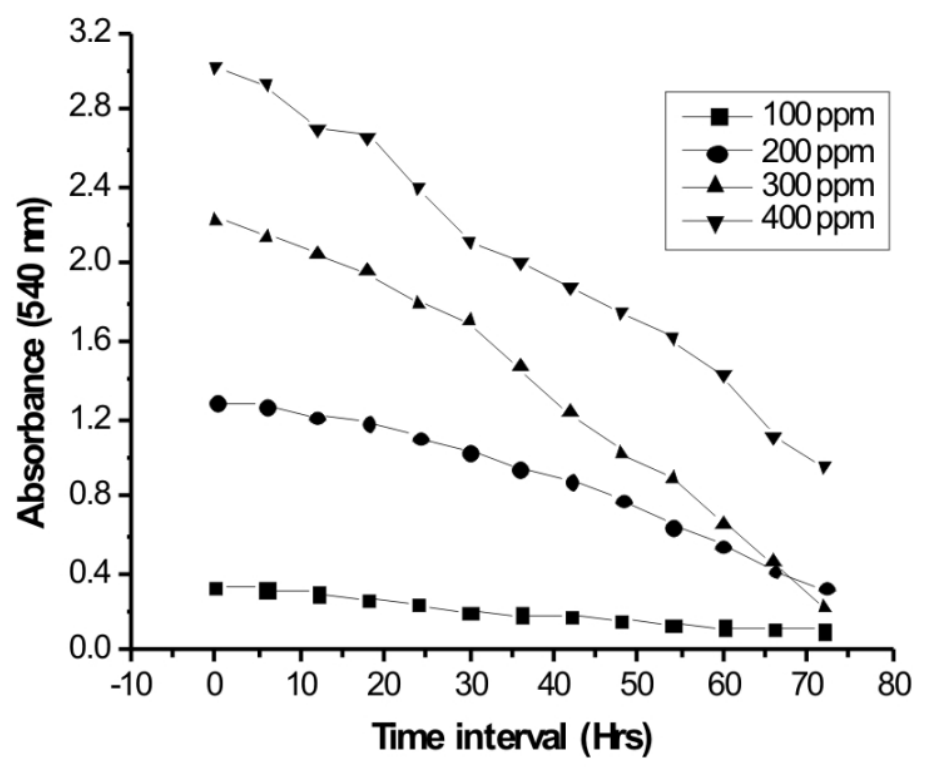

Fig. 6. Reduction of chromium by consortium of microbes

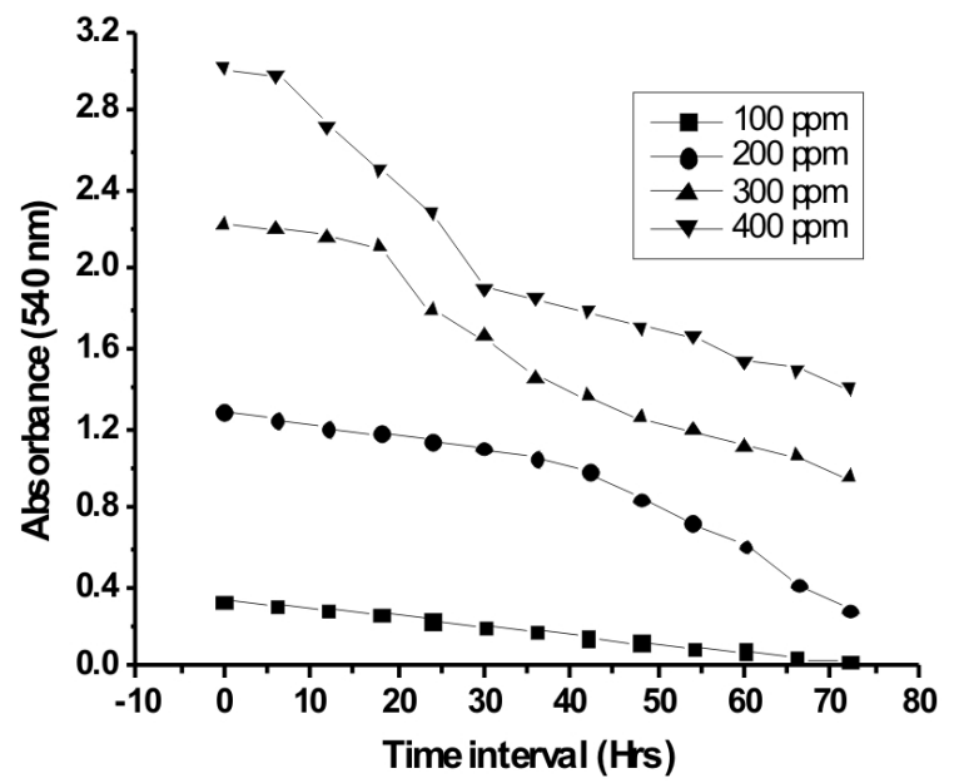

Fig. 7. Reduction of chromium by Pseudomonas putida 


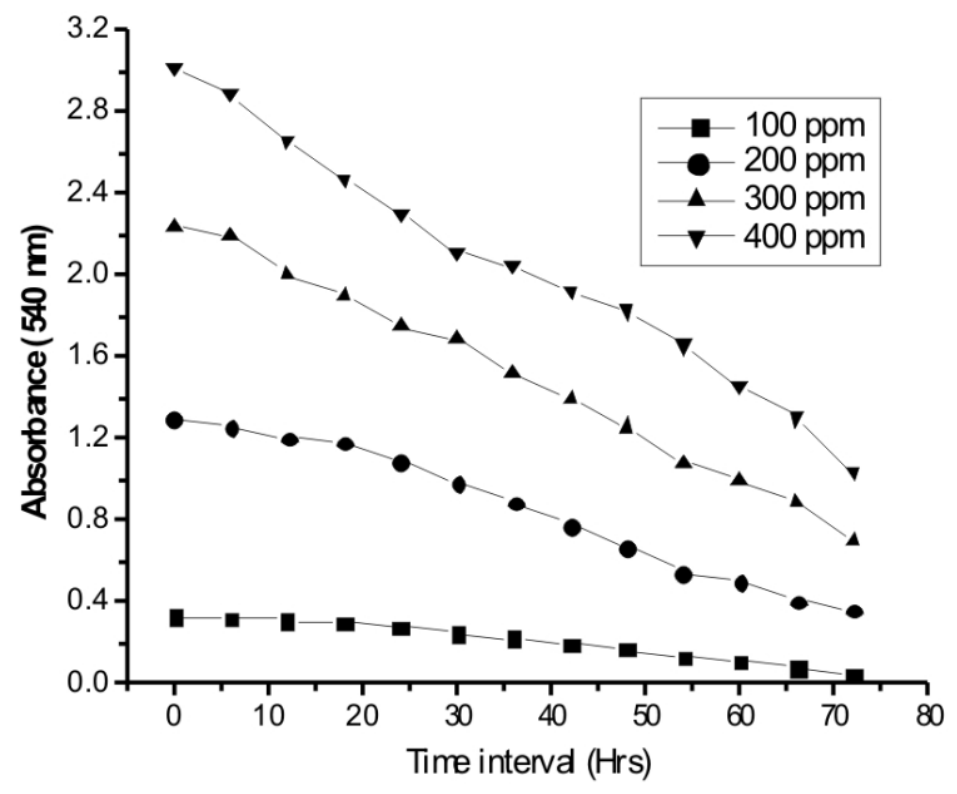

Fig. 8. Reduction of chromium by Pseudomonas alcaligenes

proceedings. The initial reading was taken immediately after the inoculation of the bacterial isolates from which the reduction of chromium was monitored periodically. The chromium concentration was varied from 100 to $400 \mathrm{ppm}$

The maximum chromium reduction of $90.41 \%$ was observed (Figure 6) in the consortium of microbes at concentration of $300 \mathrm{mg} / \mathrm{L}$. Reduction of $92.24 \%$ and $85.45 \%$ in $100 \mathrm{mg} / \mathrm{L}$ of culture was observed In Pseudomonas putida (Figure 7) and Pseudomonas alcaligenes (Figure 8). It is inferred that chromium reduction can occur even at higher concentration and the consortium of bacteria which has the higher rate of reduction in the chromium with its maximum amount in it. $\mathrm{Cr}(\mathrm{VI})$ reduction occurred even at the highest concentration (Liu et al. 2006).

The results obtained were also satisfactory when these strains were enriched further. There is an increase in their chromium reducing capacity as they tend to develop resistance and adapt to higher toxic environment. The percent of chromium reduction was measured using the following formula

Chromium removal $(\%)=$

$\frac{(\text { Initial absorbance }- \text { Final absorbance) }}{\text { Absorbance of uninoculated broth }} \times 100$

\section{G. Removal percentage of chromium}

The initial concentration for consortium of microbes, Pseudomonas putida and Pseudomonas alcaligenes is $1.0 \mathrm{~mL}$. The optimized $\mathrm{pH}$ and temperature are 7.0 and $30^{\circ} \mathrm{C}$ respectively

The percentage reduction of chromium for different chromium concentration for consortium of microbes, Pseudomonas putida and Pseudomonas alcaligenes are presented in Figures 9, 1011 respectively.

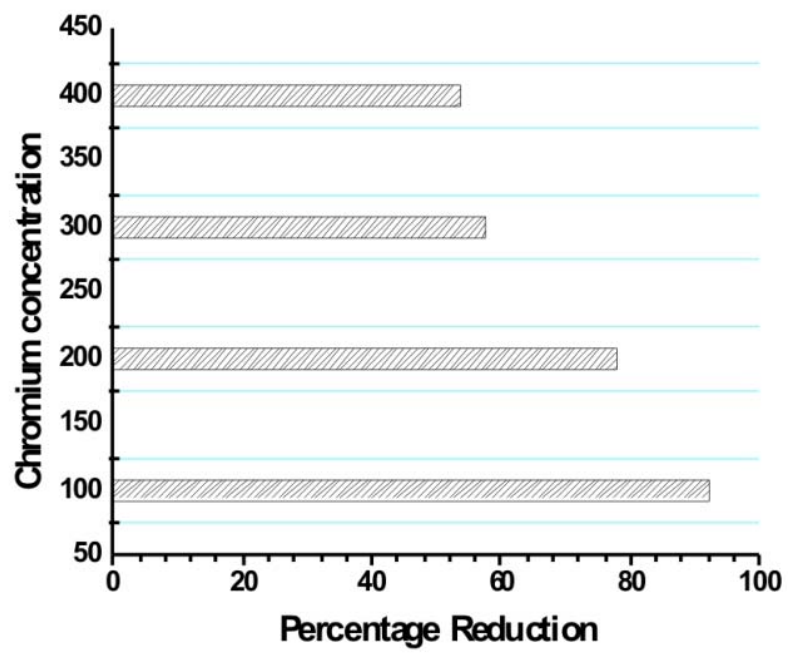

Fig. 9. Percentage reduction by Consortium of 


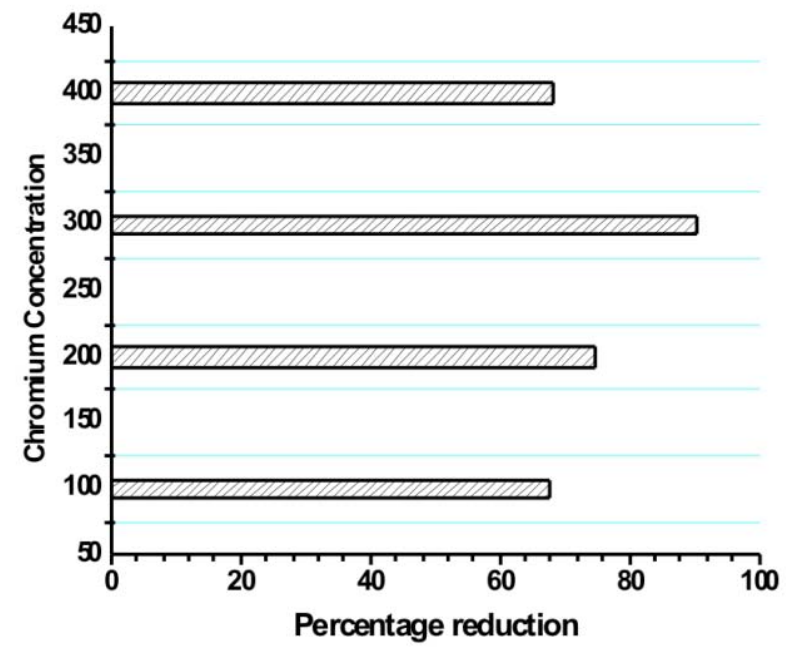

Fig. 10. Percentage reduction by Pseudomonas Putida

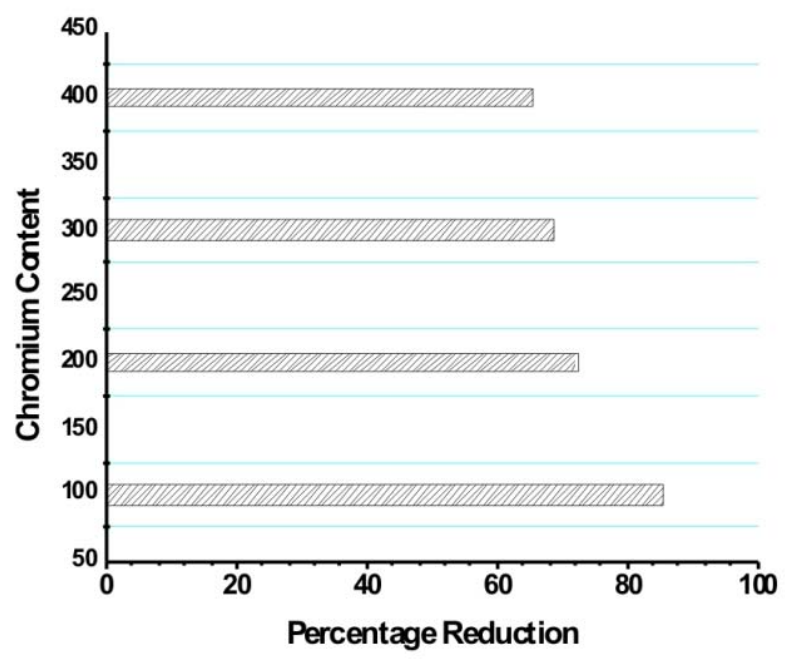

Fig. 11. Percentage reduction by Pseudomonas alcaligenes

\section{CONCLUSION}

Chromium reducing capacity of organisms which were isolated from site highly contaminated with chromium has the organisms which can tolerate higher concentration of chromium. They also have the ability to reduce high concentration of chromium when compared to the other organisms. The consortium of organisms has the highest synergic effect in reducing chromium to greater extend when compared with the individual microbes used.

The growth of microbes in the chromium amended medium has no way effected in the reduction of chromium. The chromium reduction has occurred much larger in higher initial concentration of chromium in the consortium of microbes. The other Pseudomonas $s p$. isolates showed less tolerance to higher initial concentration of microbes and reduction occurred in the lower initial concentration of chromium when compared with the consortium of microbes.

\section{REFERENCES}

[1] Abhipsa Sarangi, Chandraraj Krishnan, 2008 'Comparison of in vitro $\mathrm{Cr}(\mathrm{VI})$ reduction by CFEs of chromate resistant bacteria isolated from chromate contaminated soil', Bioresource Technology, 99 (10) pp.4130- 4137.

[2] Bader.J.L, et.,al 1999, 'Chromium resistant bacterial populations from a site heavily contaminated with hexavalent Chromium', Water, Air, and Soil Pollution, 109 (1-4) pp.263-276.

[3] Bopp. L.H. and H.L.Ehrlich, 1988. Chromate resistance and reduction in Pseudomonas fluroscence strain LB300. Arch. Microbiol., 150: 426-431.

[4] Cervantes. C, Campos-Garca. J, Devars. S, Gutierrez-Corona. F, Loza-Tavera. H, Torres-Guzman. J.C, Moreno-Sanchez. R, (2001). Interactions of chromium with microorganisms and plants. FEMS Microbiology Review, 25: 335-347.

[5] Cetin,D., et al., 2007,'The treatment of textile wastewater including chromium(VI) and reactive dye by sulfate-reducing bacterial Enrichment', Journal of Environmental Management. 88 (1), pp.76-82.

[6] Cher J.M. and Hao O.J. 1996, Environmental Factors and modeling in microbial chromium (VI) reduction Water Environmental Research 68 (7) pp1156-1165.

[7] Cheung.K.H., Ji-Dong Gu, 2003, 'Reduction of chromate by an enrichment consortium and an isolate of marine sulfate-reducing bacteria', Chemosphere 52 (9)pp:1523-1529.

[8] Cheung.K.H., Ji-Dong Gu, 2007, Mechanism of hexavalent chromium detoxification by microorganisms and bioremediation application potential:A review, International Biodeterioration \& Biodegradation, 59 (1) pp: 8-15.

[9] Costa, M., 2003. Potential hazards of hexavalent chromate in our drinking water. Toxicology and Applied Pharmacalogy, 188, pp. 1-5.

[10] Di Fang, Li-Xiang Zhou,2007, 'Enhanced Cr bioleaching efficiency from tannery sludge with coinoculation of Acidithiobacillus thiooxidans TS6 and Brettanomyces B65 in an air-lift reactor', Chemosphere 69 (2) pp. 303-310.

[11] Donghee Park a, Seong-Rin Lim, 2007, 'Reliable evidences that the removal mechanism of hexavalent 
chromium by natural biomaterials is adsorption-coupled reduction', Chemosphere 70 (2) pp:298-305.

[12] Elena Fulladosa, Valerie Desjardin et al 2006 ' $\mathrm{Cr}(\mathrm{VI})$ reduction into $\mathrm{Cr}(I I I)$ as a mechanism to explain the low sensitivity of Vibrio fischeri bioassay to detect chromium pollution', Chemosphere 65 (4) pp:644-650.

[13] Fude L, Harris B, Urrutia MM et al. 1994 Reduction of $\mathrm{Cr}(\mathrm{VI})$ by a consortium of sulphate reducing bacteria (SRB III), Applied Environmental Microbiology, 60, pp. 1525-1531.

[14] Gonul Donmez and Nur Kocberber, 2007, 'Isolation of hexavalent chromium resistant bacteria from industrial saline effluents and their ability of bioaccumulation', Enzyme and Microbial Technology 36 (5-6) pp: 700-705.

[15] Gibb. H.J, Lees. P.S, Pinsky. P.F, Rooney. B.C, 2006, Lung cancer among workers in chromium chemical production. American Journal of Industrial Medicine, 382, pp.115-126.

[16] Guha. H, Jayachandran. K, Maurrasse. F, 2001, Kinetics of chromium (VI) reduction by a type strain Shewanella alga under different growth conditions. Environmental Pollution, 115:209-218.

[17] Hoang. D.L and Lieske H 2000, 'Temperature-programmed reduction study of chromium oxide supported on zirconia and lanthanazirconia', Thermochimica Acta 345 (1), pp: 93-99.

[18] Iqbal Ahmad.,et., al. 2005, 'Heavy Metal Biosorption potential of Aspergillus and Rhizopus sp. isolated from Wastewater treated soil', Journal of Applied Sciences and Environmental Management, 9 (1) pg:123 - 126.

[19] Jeyasingh.J, Ligy Philip, 2005, 'Bioremediation of chromium contaminated soil: optimization of operating parameters under laboratory conditions', Journal of Hazardous Materials, 118 (1-3) pp:113-120.

[20] Laxman. R.S., More. S, 2002, 'Reduction of hexavalent chromium by Streptomyces griseus', Minerals Engineering 15 (11) pp: 831-837.

[21] Liu G.Y., W.H.Xu, M.G.Zeng, X.Li and H.Gao, 2006 $\mathrm{Cr}(\mathrm{VI})$ reduction by Bacillus $\mathrm{sp}$ isolated from chromium landfill. Process Biochemistry, 41, pp. 1981-1986.

[22] Lovely D.R and Philips E.J.P, 1994, Reduction of chromate by Desulfovibrio vulgaris and its $C$ (3) cycthochrome, Applied Environmental Microbiology, 60, pp 727-730.

[23] Marisa Viera, Gustavo Curutchet, Edgardo Donati, 2003 'A combined bacterial process for the reduction and immobilization of chromium', International Biodeterioration \& Biodegradation 52 (1) pp:31 - 34 .

[24] McLean. J, Beveridge. T.J, (2001). Chromate reduction by a pseudomonad isolated from a site contaminated with chromated copper arsenate. Applied Environmental Microbiology, 67, pp. 1076-84.

[25] Mujeeb Ur Rahman, Shereen Gul, Mohammad Zahoor UI Haq 2007, Reduction of Chromium(VI) by Locally Isolated Pseudomonas sp.C-171, Turkish Journal of Biology, 31 pp. 161-166.

[26] Namasivayam.C, Sureshkumar .M.V., 2008 'Removal of chromium $(\mathrm{VI})$ from water and wastewater using surfactant modified coconut coir pith as a biosorbent', Bioresource Technology, 99 (7) pp.2218-2225.

[27] Nishioka. H, (1975). Mutagenic activities of metal compounds in bacteria. Mutation Research, 31, pp. 185-189.

[28] Ohtake, H. and S. Silver, 1994. Bacterial detoxification of toxic chromate. In: Biological Degradation and Bioremediation of Toxic Chemicals (Chaudhry. G.R.. Ed.). pp: 403-415.

[29] Pal A, Sumana Dutta and Paul A.K. 2005, Reduction of Hexavalent Chromium by Cell-Free Extract of Bacillus sphaericus AND 303 Isolated from Serpentine Soil Current Microbiology, 51 (5) pp 327-330.

[30] Pazouki. M, Keyanpour-Rad.M ,2007, 'Efficiency of Penicillium chrysogenum PTCC 5037 in reducing low concentration of chromium hexavalent in a chromium electroplating plant wastewater', Bioresource Technology 98 (11) pp.2116-2122.

[31] Petrilli, FL; DeFlora, S. (1977) Toxicity and mutagenicity of hexavalent chromium on Salmonella typhimurium. Applied Environmental Microbiology, 33, pp. 805-809.

[32] Pugh, C.T; Palmer, T.T; Carr, P.A, 2008, 'A study of significant variables and their effects on the analysis of hexavalent chromium', Journal of Chemical Health and Safety, 15, (3), pp 25-28.

[33] Romanenko. V.I., Korenkov. V.N, (1977). A pure culture of bacterial cells assimilating chromates and bichromates as hydrogen acceptors when grown under anaerobic conditions. Mikrobiologiya, 46: 414-417.

[34] Sharma. D.C, Chatterjee. C, Sharma. C.P, (1995). Chromium accumulation and its effects on wheat (Triticum aestivum L. cv. HD 2204) metabolism. Plant Science, 111:145-151.

[35] Shen, H. and Y.T. Wang. 1993. Characterization of enzymatic reduction of hexavalent chromium by Escherichia coli ATCC 33456. Applied Environmental Microbiology, 59 pp. 3771-3777.

[36] Srinath .T, Verma.T et al 2002, 'Chromium (VI) biosorption and bioaccumulation by chromate resistant bacteria', Chemosphere 48 (4) pp:427-435.

[37] Tyrone L. Daulton, Brenda J. Little et al 2007 'Microbial reduction of chromium from the hexavalent 
to divalent state', Geochimica et Cosmochimica Acta 71 (3) pp:556-565.

[38] Urvashi Thacker, Rasesh Parikh, 2007 'Reduction of chromate by cell-free extract of Brucella sp. Isolated from $\operatorname{Cr}(\mathrm{VI})$ contaminated sites', Bioresource Technology 98 (8) pp:1541-1547.

[39] Urvashi Thacker, Rasesh Parikh, 2006 'Hexavalent chromium reduction by Providencia sp.', Process Biochemistry 41 (6) pp:1332-1337.

[40] Venitt. S, Levy. L.S, 1974. Mutagenicity of chromates in bacteria and its relevance to chromate carcinogenesis. Nature 250: 493-495.

[41] Wang .P, Mori. T, Toda. K, Ohtake. H, 1990. Membrane-associated chromate reductase activity from Enterobacter cloacae. The Journal of Bacteriology, 172, pp. $1670-2$.

[42] Wang, Y.T. and H. Shen. 1995. Bacterial reduction of hexavalent chromium. Journal of Industrial Microbiology and Biotechnology, 14, 159-164.

[43] Wenjie Zhu, Liyuan Chai, 2008, 'Anaerobic reduction of hexavalent chromium by bacterial cells of Achromobacter sp. Strain Ch1', Microbiological Research, 163 (3) pp.616-623.
[44] Xu. Y.B, Feng. A.K, Sun. S.Y, (2005). Study on $\mathrm{Cr}$ (VI) adsorption capacity of given sludge. Protection of Water Resource, 21 2:27-30.

[45] Yi-Tin wang, Changsong Xiao, 1995 , 'Factors Affecting Hexavalent Chromium reduction in Pure Cultures of Bacteria', Water Research, 29(11), pp. 2467-2474.

[46] Yun-Guo Liu, Wei-Hua Xu, 2006, 'Cr(VI) reduction by Bacillus sp. isolated from chromium landfill', Process Biochemistry 41 (9) pp: 1981-1986.

[47] Zainul Akmar Zakaria, Zainoha Zakaria, 2007 'Hexavalent chromium reduction by Acinetobacter haemolyticus isolated from heavy-metal contaminated wastewater', Journal of Hazardous Materials 146 (1-2) pp. $30-38$.

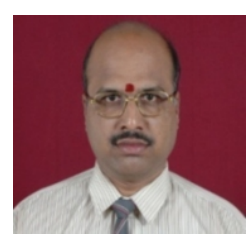

Rangasamy Parthiban is a Professor \& Head of Chemical Engineering Department in Sri Venkateswara College of Engineering, Sriperumbudur, India

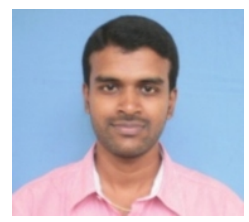

Meenatchisundaram Sivarajan is a Scientist in the Chemical Engineering division at Central Leather Research Institute, Chennai, Tamilnadu. 